\title{
Some Swiss-British Medical Relationships in the Nineteenth Century
}

\author{
By S.S.B.Gilder
}

Situated as it is on the path from France to Italy, Switzerland has for centuries been a natural stopping place on the tour of Western Europe performed by so many young Britons in the furtherance of their education. Among the wanderers have been many doctors, who in the age when Latin was the lingua franca of educated men had of course no problem of communication with foreign colleagues.

By the nineteenth century with the decay in the use of Latin linguistic barriers were arising, so that it became more natural for the Swiss to make closer relationships with their German or French speaking colleagues in a period which saw the rise to fame of such schools as those of Paris, Vienna and Berlin.

Nevertheless, as I hope to show, there were in many branches of medicine some close ties between Britain and Switzerland and a good deal of mutual influence which has persisted until today. It is impossible in the time available to give you a general sketch of the period, and I propose to take a few examples in order to make a few points such as the importance of the individual in promoting contacts or spreading new doctrine, and the obstacles to progress that can be created by a combination of chauvinism and self-interest.

As the 19th century opens, the chief link between Britain and Switzerland is undoubtedly due to the fame of the Edinburgh school of medicine, to which so many Geneva physicians in particular repaired for study and from which they brought back teachings and practices that were to colour the local medical scene for fifty years or more.

The medical faculty of the University of Edinburgh was founded in 1726 and was at first slow to gain impetus, graduating only one or two students a year in the first twenty years and then slowly gathering strength until the end of the eighteenth century and beyond, to the extent that the anatomical classes of the celebrated Professor Knox might contain several hundred listeners.

Among the many foreign students who went to Edinburgh were most of the leading figures in Geneva, as Professor Ackerknecht has pointed out in 
a contribution to the Nineteenth Congress of the History of Medicine in $1964^{1}$. It is instructive to scan some of the classical publications by Genevese physicians in the early nineteenths century and note how the choice of subjects is similar to that in eighteenth century Edinburgh, and how the thinking is similar too.

Let me take an example from among many. The famous Genevese physician J.-F.Coindet (1774-1834), who incidentally had been a President of the Royal College of Physicians of Edingurgh, published in 1817 a classical monograph entitled Mémoire sur l'hydrencéphale, noting that the term "hydrocephalus" includes a number of lesions, and reserving the term "hydrencéphale" for the acute type (associated with meningitis) and "hydrocéphale" for the chronic forms. His monograph is full of references to previous Scottish publications such as Dr. Robert Whytt's Observations on the dropsy of the brain ${ }^{2}$ in which the first clear description of tuberculous meningitis was given. Whytt (1714-1766) was elected professor of the practice of medicine in Edinburgh in 1747 and was famous for his research in what we should now call physiology, with particular reference to the nervous system. In his classification of acute hydrocephalus Coindet also follows an Edinburgh man Cheyne who produced a monograph on dropsy of the brain in $1808^{3}$.

Two other striking points emerge from a study of the Mémoire. There is a remarkably full and international list of references taken from Plouquet's Repertorium medicinae practicae which includes works from Britain, America, Germany and France; secondly Coindet published as an appendix two series of observations on meningitis, one by André de St. Clair published when he was professor of medicine in Edinburgh in 1732 and the other by John Paisley, a Glasgow surgeon, published in 1733 (the latter is said to have inspired Whytt to produce his essay of 23 pages on dropsy of the brain).

There are many other examples of the operation of the Edinburgh-Geneva axis. Louis Odier (1748-1817), also an Edinburgh M.D., produced the first continental description of meningitis in 1779 (do we note the influence of Whytt again ?) and Gaspard Vieusseux (1746-1814) also wrote on epidemic meningitis. Odier and Vieusseux were both promoters of the Jennerian

1 E.H. ACKerknecht, In Current problems in history of medicine, Basel 1966, p. 420.

2 R. WHYTT, Observations on the dropsy of the brain.

3 J. Cheyne, An essay on hydrocephalus acutus or dropsy in the brain, Edinburgh 1808. 
system of vaccination, and the latter was one of the Genevese physicians to study croup or diphtheria, which had been described in 1765 by Francis Home (1719-1813), elected professor of materia medica in Edinburgh in 1768. Ackerknecht is no doubt correct in tracing back such leitmotifs in Genevese interests as the above to a former contact with Edinburgh.

\section{The acceptance of Listerian principles}

My second example of Anglo-Swiss relationships again concerns Scotland, and is an illustration of how quickly an idea can spread if one enthusiastic individual can convince others. I refer to the speedy acceptance of Lister's principles of antisepsis in such centres as Basel and Berne. You may recall that Lister's first writings on the use of carbolic acid as an antiseptic appeared in 1867. The story of how the good tidings was brought to Basel has been well told in a monograph by Reichen ${ }^{4}$ in 1949 .

Before Listerism the state of a surgical department in Basel was not very different from one anywhere else. Operation was avoided unless absolutely necessary, so that in Basel in 1858 for instance only 9 out of 356 patients were operated on- 4 for an amputation, 2 for excision of benign tumours, one for hydrocele and two for hernia (with fatal results) so that the operating room attendant and his assistant could not have got very merry on the official bottle of wine they received on operating days. Pyaemia and tetanus were rife in the department, and an amputation stump took 100 days to heal. The mortality rate for open fractures was $50 \%$, and even the excision of a simple sebaceous cyst from the scalp, now confided to the most junior of assistants, was inevitably followed by suppuration and a hospital stay of two weeks. (You may remember that Sir Astley Cooper, the famous London surgeon, said that he took his life in his hands when he removed a sebaceous cyst from the head of George III.)

In these circumstances a young Basel surgeon, Johann Jakob Bischoff (1841-1892) from Professor Socin's department, took leave of absence to study abroad. In the early spring of 1867 he went to Vienna, Prague, Strasbourg, London and finally Glasgow, perhaps because he had heard of what

4 G. Rerchen, Die chirurgische Abteilung des Bürgerspitals Basel zur Zeit der Antiseptik, Veröffentlichungen der Schweizerischen Gesellschaft für Geschichte der Medizin, Nr.18, Aarau 1949. 
Lister was doing. He reached Glasgow in 1868 and was received with the courtesy always displayed to foreign visitors. He was convinced of the efficacy of Lister's methods, but it is also his personal merit to have quickly seen the possibility of using antisepsis in childbirth and to have applied this quite soon after his return. A further trip to Dublin and Paris was interrupted by the news that he had been appointed to the charge of the new obstetric department at the Bürgerspital in Basel. On his return he discussed Lister's principles with Socin, and fortunately the professor proved receptive to his pupil's enthusiasm. Even the fact that the first two cases they employed the method on in March 1868 were unsuitable (they opened a abscess which turned out to be tuberculous, for example), did not deter them from further trials. Later Socin ${ }^{5}$ described how he had modified Lister's methods with success. In 1871 another of Socin's surgical assistants went to watch Lister at work and had an instructive week there. By this time Lister had transferred to Edinburgh and Rudolf Massini (1845-1902) described in the Correspondenz-Blatt für Schweizer Ärzte in $1872^{6}$ the details of his observations. He found the then Edinburgh Royal Infirmary an «uraltes finsteres Gebäude» in a nasty side street of the old town, with the worst architectural features of any hospital in Europe, which made Lister's results all the more remarkable. Next year, we find Massini ${ }^{7}$ abstracting a lecture by Schultze in Berlin on Listerism, and pointing out that there were still a majority of doubters and indifferent persons around, but that in the surgical clinics of Basel under Socin and Berne under Kocher acceptance of antisepsis was complete.

The greatness of Theodor Kocher as a surgeon is now beyond dispute and it was characteristic of the man that already in 1867, the year of Lister's publication, he was applying antisepsis at the Inselspital where he was now an assistant, to bring the mortality rate down from $15 \%$ to $9 \%$ in a year. The proof of his responsability for this change has been pointed out by Hintzsche ${ }^{8}$. In 1869 Kocher left the Inselspital to become a general practitioner in Berne and the mortality shot back to $14 \%$. By the mercy of providence in 1871 Kocher was brought back as professor and by 1873 he had the mortality down again to $9 \%$.

5 A.Socin, Korrespondenzblatt Schweizer Ärzte 6 (1876) 707.

6 R.MAssini, ibid. 2 (1872) 314.

7 R.MAssinI, ibid. 3 (1873) 249.

8 E. Hintzsche, Schweizerische Ärztezeitung 48 (1967) 763. 
One might add en passant that one reason for opposition to Lister's methods was the expense of the carbolic dressings he used. Socin fought repeatedly with the hospital administration in Basel over this, but always won.

One might also add that an additional reason for Kocher's quick acceptance of antisepsis lay in his study tour in London in 1866 which gave him an exceptional command of English and incidentally, seems finally to have decided him to become a surgeon - to the benefit of the whole world.

Let me return a moment to Bischoff, whom we left taking over the Basel obstetric department. In April 1868 he became extraordinary Professor of Obstetrics in Basel, an office he combined with that of director of the maternity hospital until 1886. He reasoned that the female genital tract after labour was a type of wound and that puerperal sepsis was a wound disease and as such should be preventable by carbolic acid. He described his technique in the Correspondenz-Blatt in $1875^{9}$ and his figures for mortality from puerperal sepsis speak for themeselves:

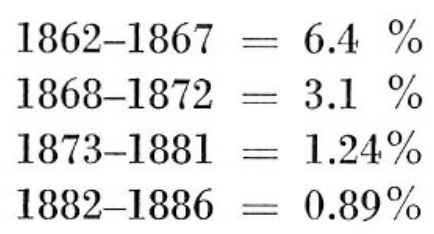

There is a detailed review of Bischoff's achievements in 100 Jahre Geburtshilfe und Gynäkologie in Basel, in a chapter by Prof. Buess ${ }^{10}$.

\section{Kocher and the thyroid}

I have just narrated the story of a rapid acceptance of a British technique by Switzerland. Now let me present you with the reverse-the exceedingly slow acceptance of a Swiss technique by Britain. It concerns the great Theodor Kocher (1841-1917) of Berne and his operation of thyroidectomy. After a good deal of thought I am still puzzled by the fact that years after Kocher had proved conclusively that one could operate on the thyroid for Graves-Basedow disease with success and with little risk, surgeons in Britain

9 J. J.Bischoff, Korrespondenzblatt Schweizer Ärzte 5 (1875) 645.

10 T. Koller, H.Stamm, and K.StÄUble (editors), 100 Jahre Geburtshilfe und Gynäkologie in Basel, Basel 1970. 
remained generally sceptical, as they did about his operation of ligation of thyroid arteries for the same malady. When he died in 1917 the Lancet said: «His success in the treatment of exophthalmic goitre by ligation of arteries under local anaesthesia was widely disbelieved by those who had not visited his clinic.» Yet surgeons from all over the world beat a path to his door for many years, and his assistants and students went out to spread his operative techniques far and wide. His activity in thyroid surgery dated back to the seventies, and he had already shown by analysis of his first hundred thyroidectomies that complete excision of the gland led to myxoedema (cachexia strumipriva) and that therefore a little of the gland must be left. I will not enter into the controversy over priority for the discovery that total removal of the thyroid leads to myxoedema, except to say that according to Bornhauser (Zur Geschichte der Schilddrüsen- und Kropfforschung im 19. Jahrhundert, Aarau 1951) a Dr Fetscherin of Zäziwil first drew Kocher's attention to a case of postoperative myxoedema in 1874, but both missed the significance of the observation until Jacques-Louis Reverdin of Geneva told Kocher about a series of his own cases while on a steamer trip in 1882 (see J. L. Reverdin, by Henri Reverdin, Aarau 1971). He had demonstrated with his meticulous and infinitely patient technique, with such strict haemostasis that the towels around the wound remained white, that it was possible to perform thyroidectomy with an acceptably low mortality. When he opened the discussion on surgical treatment of Graves's disease at the British Medical Association annual meeting in London in July 1910 he could look back on 4,394 thyroidectomies, 469 for Graves's disease, with a mortality rate now reduced to $1.3 \%$.

He was still preaching to the unconverted in 1910 when he exhorted his British hearers to "go and tell your friends practising internal medicine to help in the accomplishment of a cure of that severe and dangerous disease, and not oblige the surgeon by a late operation, as Crile says, 'after the ship has gone on a rock, to deal with the wreckage!'”

At this meeting he was immediately followed by Dr. Hector Mackenzie, physician of St.Thomas's Hospital, who proceeded to exhibit that chauvinism which London medical schools of the period were still noted for. He said that he did not believe that thyroid overactivity was the fons et origo mali in Graves's disease, even if it might cause the main symptoms. Therefore "I do not expect that temoval of the goitre or part of it will cure the disease. But I am quite willing to be convinced by results. Personally, I have seen no cases that I should consider cured by operation." 
At St. Thomas's Hospital (a leading London teaching hospital) 13 operations had been performed with five deaths, and only five improvements. He then said of Kocher: "I congratulate him but I cannot believe that he gets the same kind of cases to operate on as we do here". (In other words, never trust a foreigner!)

Kocher's main supporter in the debate was a Canadian, H.A.Bruce of Toronto, who had cured 14 out of his first 20 cases and improved another five. He had also collected some statistics of over 1000 cases operated on by Kocher, Garré, Mayo, Crile (a leading American follower of Kocher) and others. The mortality was $4 \%$, and Garré had a $16 \%$ cure rate and $85 \%$ marked improvement. This should answer Mackenzie.

But the British came round at last, as witness the tribute by the greatest of British surgeons of the age, Sir Berkeley Moynihan, in an obituary note on Kocher in the British Medical Journal for 1917 "11: "With the death of Kocher, the world loses its greatest surgeon". Moynihan listed Kocher's many accomplishments in surgery, many of which have been overlooked, such as his pioneering work in neurosurgery that inspired Harvey Cushing, greatest of American brain surgeons. He went on to say: "Infinite accuracy, infinite care, infinite patience gave him results as near to absolute perfection as it is possible for surgery to go." And that from a supreme egoist like the late Lord Moynihan was tribute indeed.

\section{Switzerland and tuberculosis}

For my final example let me take an instance of something which again the British were a little slow to take up, but in which they later displayed enthusiasm beyond that of any other race. I refer to the high altitude treatment of pulmonary tuberculosis.

As far as Britain is concerned, my story goes back to 1840 , when a general practitioner in Sutton Coldfield, Warwickshire, published a little essay on the treatment and cure of pulmonary consumption. Dr. George Bodington (1799-1881) suggested what were then revolutionary ideas on the treatment of pulmonary tuberculosis. Patients were at that time kept in hot rooms and given a low diet, and Bodington thought this was all wrong. They needed fresh air, a nourishing diet and graduated exercise. He also

11 Sir Berkeley Moynihan, Brit. med. J. 2 (1917) 168. 
foresaw the use of special hospitals for tuberculosis. He put his principles into practice among his patients but was attacked in the Lancet for his absurd ideas.

As you know, in the "seventies Davos Platz was already becoming famous as a resort for the tuberculous, but there is very little hint of this in the medical press of Britain until suddenly in 1879 the subject appears and begins to excite a good deal of contriversy. Three names appear regularly among the protagonists of high altitude treatment in Switzerland. First is Sir Clifford Allbutt (1836-1925) who became Regius professor of medicine in Cambridge in 1889. He was a versatile man and perhaps his interest in Davos, freely expressed at a discussion at the B.M.A. meeting in 1879, was partly due to his exploits as an Alpine climber.

Then comes Dr. C.T. Williams (1838-1912), who was obliged to spend two winters in France and Italy for his health soon after qualifying in medicine in 1864. He became a physician to the Brompton Chest Hospital in London, which his father had helped to found, and he was a pioneer in high altitude and sanatorium treatment.

Third is Dr. Alfred Tucker Wise, who actually obtained his Swiss Federal Diploma in Medicine in 1891, long after he had been advocating by his personal example and his writings the benefits of the Swiss Alps. His experience was ultimately summarized in a book Alpine winter in its medical aspects $^{12}$ in which he pays tribute to Bodington for his views on the efficacy of cold pure air in phthisis, and refers to the history of Davos, which is probably familiar to you.

The first studies of the effects of the Davos climate were made by Dr. Spengler on the famous partients, Hugo Richter and Dr. Unger in 1865, but the first Englishman to arrive there for his tuberculosis was a Mr. Walters in 1869. Dr. Wise in 1885 finds that Davos is already being spoiled by the influx of tourists with the accompanying smoke and noise. He then discusses the Engadine and St.Moritz (launched in 1882 as a rival to Davos but already growing too fast) which had already become an English colony. One London physician alone had already sent fifty patients, and it seems that Herr Badrutt, a local hotelier, had collaborated to establish an English physician, Dr. Holland, in the Kulm hotel. There was also an English doctor, Dr. Haggard, at Davos, but it is not clear to what extent they were permitted to practise. There are angry comments in the

12 A.T. WISE, Alpine winter in its medical aspects, 2nd edition, London 1885. 
Lancet in 1893, when two editorials appeared entitled "Professional exclusiveness in Switzerland", complaining that foreign doctors were obliged to possess the Federal diploma to practise medicine. Yet, says the writer of this stern warning to Switzerland, "Lucerne and the Grisons for much of the year are so completely occupied by the English speaking public that they may almost be regarded as British possessions." There speaks the voice of England at the zenith of her power!

Back in 1879 however the rush was only starting, and there were prophets of disaster among the medical profession. Dr. Williams read a paper to the Medical Society of London that year on the characteristics of climate in Davos and the Engadine in relation to treatment of phthisis, but he was not convincing enough. Dr. Cockle said that many cases were cured without climatic change just by staying at home, and Dr. Thompson was proud to record that he had dissuaded many patients from going to the Alps. Dr. Leared thought a reaction was already setting in against Davos (how wrong he was) and made some irrelevant observations, such as that there was no tuberculosis in the Jordan Valley below sea level.

A Dr. Hassall, physician to the National Hospital for Consumption, Ventnor (and therefore not without interest in the venue of cure) wrote an attack on Davos which was published in the Lancet that year, and recounted his own breathlessness in Davos (no wonder, since he was just recovering from pneumonia), and his dismay at the quantities of brandy prescribed and the lack of fresh vegetables and the usual drugs employed in Britain. As far as he was concerned, Ventnor was just as good. However, Dr. Carl Ruedi of Davos wrote a reasoned reply in which he refuted all Hassall's points, and former patients who had been to Davos rose in its defence. Dr. Burney Yeo (1835-1914), physician to King's College Hospital, London, was angry because his own early writings on Davos in 1876 had been overlooked and people seemed to think that Sir Clifford Allbutt had invented the place. But then as Yeo's biographer says, Dr. Yeo was more successful with patients than with colleagues. He describes him as of a sensitive and assertive nature.

It is interesting to note to what extent during the next decade the Swiss Alps got a hold on medical thinking. For example, the Lancet editor writes in 1891 after the first attempts of Koch to treat tuberculosis with vaccine that an unwarranted flight from the sanatoria to Berlin was taking place, and that it was unwise to exchange the brilliant atmosphere of the higher Alps for the raw air of Berlin in midwinter. The earlier cases will be more 
comfortable in Davos or St. Moritz and there is no evidence that the new treatment will aid advanced cases.

From the above examples you will see that the traffic in medical ideas and in medical practice has not been a one way one. Both parties have gained something from Anglo-Swiss contacts and no doubt they will continue to do so, as long as intelligent men and women with open minds continue to enter our profession. 